\title{
Forage conservation efficiency and lactation response to bahiagrass conserved as barn-stored hay, outdoor-stored hay, or baleage
}

\author{
M. E. McCormick, ${ }^{\star 1}$ K. J. Han, ${ }^{\star}$ V. R. Moreira, ${ }^{*}$ D. C. Blouin, $\dagger$ and S. Forbes ${ }^{\star}$ \\ ${ }^{*}$ AgCenter Southeast Research Station, Louisiana State University, Franklinton 70438 \\ †Department of Experimental Statistics, Louisiana State University, Baton Rouge 70803
}

\begin{abstract}
A study was conducted to determine the effect of conserving bahiagrass as outdoor-stored hay (OSH), barn-stored hay $(\mathrm{BSH})$, or baleage (BAL) on storage losses and lactation performance by Holstein cows. For baleage production, bahiagrass forage was cut and allowed to dry for $20 \mathrm{~h}$ in windrows, baled $(1.2 \times 1.4$ $\mathrm{m})$, and individually wrapped with white stretch film. Forage cut on the same day was dried to hay stage, baled $(1.2 \times 1.6 \mathrm{~m}$ round bales), and stored either outdoors $(\mathrm{OSH})$ or in an enclosed hay barn (BSH). Bales were core sampled and weighed at harvest and again following a 6-mo storage period. At the end of the storage period, 30 multiparous mid-lactation Holstein cows $[39.2 \pm 5.6 \mathrm{~kg}$ of $3.5 \%$ fat-corrected milk and $142 \pm 27$ $\mathrm{d}$ in milk (DIM)] were stratified according to milk yield and DIM and randomly assigned to 1 of the 3 forage conservation treatments. Cows were trained to Calan feeding gates and were offered a common partial mixed ration in a 10-d covariate period followed by a $42-\mathrm{d}$ treatment feeding period. Forage dry matter losses were highest for $\mathrm{OSH}$, but were similar between $\mathrm{BSH}$ and baleage. Conservation method had little effect on poststorage crude protein levels, but acid detergent fiber and neutral detergent fiber concentrations were higher in $\mathrm{OSH}$ than in either $\mathrm{BSH}$ or BAL, which resulted in a $12.8 \%$ depression in net energy for OSH compared with the other treatments. Dry matter intake (20.5 vs. 22.1 $\mathrm{kg} / \mathrm{d}$ ) and milk yield (28.2 vs. $30.2 \mathrm{~kg} / \mathrm{d}$ ) tended to be lower for OSH than for BSH. Lactation performance was similar between BSH and BAL: 29.6 versus 28.7 $\mathrm{kg} / \mathrm{d}$ of fat-corrected milk, respectively. No differences in milk composition, feed efficiency, body weight, or body condition score change related to conservation system were observed. In this study, dry matter losses and lactation performance from bahiagrass conserved as baleage were similar to that of similar forage stored
\end{abstract}

Received September 7, 2010.

Accepted January 6, 2011.

${ }^{1}$ Corresponding author: memccormick@agctr.lsu.edu indoors as hay, whereas hay stored outside resulted in less satisfactory forage quality.

Key words: conservation system, bahiagrass, hay, baleage

\section{INTRODUCTION}

Most pasture-based dairies in Louisiana continue to rely heavily on locally grown hay crops derived primarily from bahiagrass (Paspalum notatum L.) and bermudagrass (Cynodon dactylon L.) to meet conserved forage needs (Leonardi et al., 2008). Normally, Louisiana hay crops are of low nutritive value due to a combination of factors including environmental stress, harvesting at advanced stages of maturity, and high field losses (Han and McCormick, 2010). In addition, high humidity and rainfall in the area often inflict tremendous storage losses on outdoor-stored hay with concomitant increases in hay fiber content that further lowers crop digestibility (Nelson et al., 1983). Consequently, an increasing number of cattle producers in the southern United States are adopting bale-wrapping technology to ensure a more consistent quality of hay crops.

Storage losses of stretch wrap-produced baleage are usually less than $10 \%$ of initial weight for cool-season grasses and legumes (Straub et al., 1990; Collins et al., 1995; McCormick et al., 1998). Wisconsin researchers (Straub et al., 1990) reported a $6.35 \%$ DM loss for alfalfa (Medicago sativa L.) baleage following an 8-mo storage period. Kentucky researchers (Collins et al., 1995) reported a 3.6\% loss in DM for fescue (Festuca arundinacea L.) baleage stored for 1 yr. This value is similar to the $4.5 \%$ DM loss recorded in Louisiana for annual ryegrass (Lolium multiflorum L.) baleage stored for 6 mo (McCormick et al., 2002).

Little is known concerning the ensiling characteristics and storage losses of summer perennial forages conserved as baleage. Bates et al. (1989) compared 2 bermudagrass varieties, 'Coastcross-1' and 'Suwannee', harvested direct cut $(27.4 \% \mathrm{DM})$ or following a 23.5 -h wilt $(45.2 \% \mathrm{DM})$ and stored as baleage for 4 to $6 \mathrm{mo}$. No differences in ensiling characteristics or storage losses related to variety were noted, but wilting increased bale $\mathrm{pH}$ from 6.10 to 6.65 , lowered silage ammonia concen- 
trations, and decreased storage losses from 11.7 to $3.9 \%$ of DM. Initial water-soluble carbohydrate concentrations averaged $2.17 \%$ of dry weight, which likely limited bermudagrass baleage fermentation. By comparison, pre-ensiled annual ryegrass forage contained 5 times as much soluble carbohydrate and, following 6 mo of storage, the resulting baleage contained 4 times as much lactic acid, with a final $\mathrm{pH}$ of 4.8 (McCormick et al., 1998). Data on storage losses or ensiling characteristics of bahiagrass conserved as baleage are not available.

Few studies have been conducted to assess the feeding value of baleage crops for lactating dairy cows. Canadian researchers (Petit et al., 1993) compared timothy (Phleum pratense L.) conserved as conventional haylage and as round bale silage. Cows consumed $17.9 \%$ less baleage than haylage and produced $15.4 \%$ less milk; however, feed efficiencies were similar between the diets. In a Louisiana study (McCormick et al., 1998), annual ryegrass haylage consumption was $17.2 \%$ higher than same-day-harvested baleage, but milk yield was only $5.3 \%$ higher.

At present, no dairy lactation comparisons between same-day-harvested forage stored as hay and baleage are available. In many regions of the world, early harvest of cool-season forages as hay is limited due to high humidity and rainfall. Because of shorter wilting time requirements, baleage harvesting of annual ryegrass (McCormick et al., 1998) and orchard grass (Dactylis glomerata L.)-fescue-clover mixtures (Borreani et al., 2007) were possible 2 to 4 wk earlier than similar forage conserved as hay. In both lactation performance studies, the earlier harvested baleage crops were higher in protein and energy than the later harvested hay crops, resulting in improved DMI, milk yield, and feed efficiency.

Nutritional value of warm-season baleage crops has been evaluated exclusively in growing ruminants (Kunkle et al., 1988; Berthe et al., 1991). In a Florida study (Berthe et al., 1991), forage DM content at baling was identified as a major factor governing performance of crossbred beef cattle. Forage intake increased $19 \%$ as baleage DM increased from 26 (direct cut) to $44 \%$ (4-h wilt). Growth rates of calves receiving high DM baleages equaled or surpassed that of animals fed sameday-harvested bermudagrass hay.

Typically, tropical forages are lower in water-soluble carbohydrates and higher in fiber than cool-season forages. As a result, summer-grown baleage crops tend to have lower lactic acid concentrations and a higher $\mathrm{pH}$ compared with cool-season baleages (González and Rodriguez, 2003; Han et al., 2006). High pH tropical baleages are prone to exhibit considerable mold, particularly on the bale exterior. Poor fermentation characteristics and high fiber content limited intake of tropical baleage to less than $2 \%$ of BW in growing cattle (González and Rodriguez, 2003). In contrast, yearling beef cattle fed well-preserved alfalfa baleage consumed more than $3 \%$ BW in forage DM (Han et al., 2006).

The objective of the present study was to determine DM and nutrient losses of bahiagrass stored for approximately 6 mo as outdoor hay, indoor hay, or baleage. A second objective was to evaluate conservation method effects on lactation performance of Holstein cows.

\section{MATERIALS AND METHODS}

\section{Forage Production, Storage, and Sampling}

A 4.9-ha field of the tetraploid bahiagrass, Paspalum notatum var. latiflorum, 'Argentine' was used to generate the needed forage for the conservation-feeding study. Bahiagrass regrowth was broadcast fertilized in mid June with $449 \mathrm{~kg} / \mathrm{ha}$ of a blended fertilizer containing $24 \%$ nitrogen, $10 \%$ phosphate, and $17 \%$ potash. Twenty-seven days later at approximately $1000 \mathrm{~h}$, a $50-\mathrm{cm}^{2}$ quadrat of forage was cut to a height of 1.8 $\mathrm{cm}$ from 8 random locations throughout the field to provide an estimate of forage mass. These samples were also used to determine plant composition. On the following day at approximately $1400 \mathrm{~h}$, the entire 4.9-ha field was harvested with a Kuhn model FC-300G disc cutter equipped with a flail-type conditioner (Kuhn North American Inc., Brodhead, WI). Approximately $25 \%$ of this 35 -d-old bahiagrass regrowth exhibited seed heads at harvest. Forage remained in 1.2-m windrows for approximately $20 \mathrm{~h}$, after which every third windrow was baled with a Vermeer 554 round silage baler (Vermeer Manufacturing Co., Pella, IA). Each round bale $(1.2 \times 1.4 \mathrm{~m})$ was tagged with a prenumbered plastic calf ear tag immediately after baling to aid in bale identification. Each bale was core-sampled to a depth of $45 \mathrm{~cm}$ in 4 locations, and collected forage was composited and stored on ice until processed in the Southeast Research Station Forage Quality Laboratory (Franklinton, LA). After sampling, bales were transported to a central location and weighed on a digitized $(0-4545 \pm 0.45 \mathrm{~kg})$ platform scale (Rice Lake Weighing Systems, Rice Lake, WI) before being individually wrapped (Ag Wrap, Ag Nation Products Inc., Canton, $\mathrm{OH})$ in 6 layers of $25-\mu \mathrm{m}$-thick, white plastic film stretched 50\% (Silage Wrap Sunfilm, AEP Industries Inc., Chino, CA). All bales were wrapped within $1 \mathrm{~h}$ after baling. After wrapping, bales were moved to a well-drained location and stored outside on the ground. Hereafter, wrapped bahiagrass bales will be designated as bahiagrass baleage (BAL).

The remaining forage was tedded on $\mathrm{d} 2$ and $\mathrm{d} 3$ postharvest and baled as dry hay $(1.2 \times 1.6 \mathrm{~m}$ round 
bales) approximately $70 \mathrm{~h}$ after initial harvest. Bales were core- sampled and weighed as described above. Every other dry bale was placed outdoors on the ground in a well-drained site (outdoor-stored hay, $\mathbf{O S H}$ ) or stored indoors in a metal-sided hay barn (barn-stored hay, BSH). A total of $14 \mathrm{BAL}, 10 \mathrm{BSH}$, and $10 \mathrm{OSH}$ bales were produced from this initial harvest.

Thirty-five days later (late August), headed third-cut regrowth was harvested from the same 4.9-ha bahiagrass field. Bale silage and hay production procedures were identical to those described earlier. Twenty bales of BAL and 12 bales each of BSH, and OSH were produced, but only 8 bales from each treatment were sampled and weighed. The purpose of repeating the forage conservation treatments over a second harvest was to acquire sufficient forage to evaluate conservation method effects on lactation performance of Holstein cows.

Following a 6-mo storage period, bales were sampled and weighed and subsequently used in a feeding trial with lactating Holstein cows. Bales were fed in the order conserved (i.e., earliest harvest to latest harvest).

\section{Forage Feeding, Animal Handling, and Sample Analyses}

Thirty multiparous mid-lactation Holstein cows (39.2 $\pm 5.6 \mathrm{~kg}$ of $3.5 \% \mathrm{FCM}$ and $142 \pm 27 \mathrm{DIM})$ were stratified according to milk yield and DIM and randomly allotted to the 3 forage conservation treatments. Cows were housed in a freestall barn equipped with Calan gates (American Calan, Northwood, NH) for measuring individual intake. Cows were trained to Calan gates for $2 \mathrm{wk}$, after which they were subjected to a 10-d standardization period, followed by a $21-\mathrm{d}$ treatment feeding period for cut 2 and a 21-d treatment feeding period for cut 3 . During the standardization period, cows received a diet containing approximately $55 \%$ forage and $45 \%$ concentrate. The forage portion of the diet was fed twice daily as a partial mixed ration containing $52 \%$ corn silage, $23 \%$ alfalfa hay, $14 \%$ whole cottonseed, and $11 \%$ soybean meal (DM basis). An additional daily concentrate allotment of $9.0 \mathrm{~kg}(18 \% \mathrm{CP}$ ground cornsoybean meal-mineral mix) was fed in equal $4.5-\mathrm{kg}$ portions immediately before the a.m. and p.m. milkings.

Treatment forages were ground with a flail-type hay grinder (model 2554 HayBuster, McConnell Machinery Co., Lawrence, KS) to a mean particle length of 10.2 $\pm 3.6 \mathrm{~cm}$ and stored in a concrete-floored hay barn until fed. No ground forage was retained longer than $48 \mathrm{~h}$. Ground forage treatments were weighed with a Calan Data Ranger (American Calan) and cows were individually fed morning $(0800 \mathrm{~h})$ and evening (1500 h) to leave $10 \%$ or more orts. Orts were collected and
Table 1. Effect of cutting (second vs. third) on bahiagrass yield and nutritive value ${ }^{1}$

\begin{tabular}{lcccc}
\hline & \multicolumn{2}{c}{ Cutting $^{2}$} & & \\
\cline { 2 - 3 } Item & Second & Third & $P$-value & SE \\
\hline DM yield, Mg/ha & $3.193^{\mathrm{a}}$ & $4.760^{\mathrm{b}}$ & 0.0001 & 0.21 \\
Protein, \% of DM & $15.3^{\mathrm{a}}$ & $10.9^{\mathrm{b}}$ & 0.0001 & 0.2 \\
ADF, \% of DM & $38.9^{\mathrm{a}}$ & $42.8^{\mathrm{b}}$ & 0.0001 & 0.4 \\
NDF, \% of DM & $69.5^{\mathrm{a}}$ & $73.8^{\mathrm{b}}$ & 0.0001 & 0.8 \\
NE & $1.33^{\mathrm{a}}, \mathrm{Mcal} / \mathrm{kg}$ & $1.22^{\mathrm{b}}$ & 0.0001 & 0.02 \\
Storage loss, \% of DM & $4.6^{\mathrm{a}}$ & $5.8^{\mathrm{a}}$ & 0.5213 & 1.2 \\
\hline
\end{tabular}

${ }^{\mathrm{a}, \mathrm{b}}$ Means within a row with different superscripts differ $(P<0.05)$. ${ }^{1}$ Forage analysis from samples collected $155 \mathrm{~d}$ postharvest.

${ }^{2}$ Second cutting was harvested from 27 -d regrowth in mid-July; third cutting was harvested $35 \mathrm{~d}$ after second cutting.

weighed morning and evening. Ort and partial mixed ration grab samples were collected daily and stored at $4^{\circ} \mathrm{C}$. These samples were composited weekly and used to determine forage nutrient composition and DM intake. During the study period, $5.7 \mathrm{~kg}$ DM of a corn-soybean meal-mineral concentrate containing $23.9 \pm 0.4 \mathrm{CP}$ and $5.7 \pm 0.2 \%$ ADF (DM basis) was fed twice daily immediately before milking (Table 1). Diets were designed to provide adequate energy, CP, and RUP for cows yielding $39 \mathrm{~kg}$ of 3.5\% FCM daily (NRC, 2001). Concentrate refusals were collected and weighed after each feeding. Concentrate samples were collected weekly for nutrient analyses. All concentrate and forage nutritive value analyses were conducted in the Southeast Research Station Forage Quality Laboratory.

Milk weights were automatically recorded for each cow at each milking using the Afi-Milk 2000 Information System (Germania Dairy Automation, Waunakee, WI). Morning and evening milk sample composites were collected weekly, preserved with 2-bromo 2-nitropropane-1,3-diol, and analyzed for percentage fat, percentage protein, and percentage lactose via infrared spectroscopy, and SCC was determined via flow cytometry (Louisiana DHIA, Baton Rouge). Body weights and BCS $(1=$ extremely thin, $5=$ extremely obese; Edmonson et al., 1989) were recorded on 2 consecutive days at study initiation and conclusion. Condition scores were assigned by 3 independent observers.

Pre- and poststorage bale core samples were weighed dried at $55^{\circ} \mathrm{C}$ for $48 \mathrm{~h}$ and ground through a $1-\mathrm{mm}$ screen. Ground samples were analyzed for DM and CP (micro- Kjeldahl) according to AOAC (1990) procedures. Bahiagrass ADF and NDF concentrations were determined via the detergent fiber methods of Van Soest et al. (1991). Sodium sulfite and amylase were added to NDF solutions before fiber analyses were conducted. Weekly composite bahiagrass treatment, weigh backs, and concentrate samples were analyzed for DM, $\mathrm{CP}, \mathrm{ADF}$, and NDF as described above. An estimate 
of bahiagrass net energy concentration was obtained based on the following equation: $\mathrm{Mcal} / \mathrm{kg}$ of $\mathrm{NE}_{\mathrm{L}}=2.2$ [1.085 - (0.0124 × ADF)] (Nelson and Montgomery, 1975). Concentrate mix $\mathrm{NE}_{\mathrm{L}}$ was estimated based on NRC (2001) estimates of $\mathrm{NE}_{\mathrm{L}}$ for grain supplement ingredients. Concentrations of $\mathrm{Ca}, \mathrm{K}, \mathrm{Mg}, \mathrm{Mn}, \mathrm{Zn}$, and $\mathrm{Cu}$ in concentrate, forage, and orts were determined by dry ashing, solubilizing in $20 \% \mathrm{HCl}$, and analyzing via atomic absorption spectroscopy (Analyst 300, Perkin Elmer, Norwalk, CT). Phosphorus was determined by the molybdovanadate colorimetric method (AOAC, 1990).

The general linear model was used to statistically analyze data from the forage conservation portion of the study (SAS Institute, 2001). The model included forage conservation method and forage cutting (second vs. third) as fixed effects and bales nested within conservation method by cutting as random residual error. Least squares means were generated for dependent variables with multiple comparisons adjustments based on Tukey-Kramer. Statistical differences between means were declared at $P<0.05$ and tendencies were reported at $P<0.10$.

Lactation performance data were statistically analyzed using the MIXED procedure of SAS Institute (2001). All daily intake and milk production data were reduced to cow-week means before statistical analysis. The model for the lactation performance data had treatment, week, and treatment by week as fixed effects; cows nested within treatment as random effects; and cows by week as residual error effects. Performance data collected during the standardization period were used as covariables for dependent variables. Treatment means were generated via Tukey-Kramer procedures and results are accompanied by the highest standard error.

\section{RESULTS AND DISCUSSION}

\section{Nutritive Value and Storage Losses}

Effect of cutting date on bahiagrass yield and nutritive value are presented in Table 1 . Dry matter yield was $49 \%$ higher for third- than for second-cutting bahiagrass used in the present study, likely a result of a 7-d-longer growing period and a more desirable late summer rainfall pattern (Interrante et al., 2009). Forage $\mathrm{CP}$ means were lower and fiber fractions higher for the later cutting, but DM losses were not affected. Earlier research at this unit has documented that bahiagrass ligno-cellulose levels peak in mid to late summer, resulting in substantial depressions in bahiagrass DM digestibility (Montgomery et al., 1979). These depressions in digestibility of bahiagrass from mid July
Table 2. Ingredient and chemical composition of diets (\% of DM unless otherwise noted) fed to lactating Holstein cows

\begin{tabular}{|c|c|c|c|}
\hline \multirow[b]{2}{*}{ Item } & \multicolumn{3}{|c|}{ Conservation method ${ }^{1}$} \\
\hline & OSH & $\mathrm{BSH}$ & BAL \\
\hline \multicolumn{4}{|l|}{ Ingredient composition $^{2}$} \\
\hline Bahiagrass & 45.23 & 49.16 & 42.53 \\
\hline Corn, finely ground & 32.97 & 30.60 & 34.58 \\
\hline Soybean meal, $48 \%$ CP & 19.60 & 18.20 & 20.58 \\
\hline Mineral-vitamin $\operatorname{mix}^{3}$ & 2.20 & 2.04 & 2.31 \\
\hline \multicolumn{4}{|l|}{ Chemical composition $^{4}$} \\
\hline $\mathrm{CP}$ & 19.1 & 18.4 & 19.3 \\
\hline $\mathrm{ADF}$ & 22.3 & 21.1 & 19.1 \\
\hline NDF & 38.8 & 38.7 & 35.0 \\
\hline $\mathrm{NFC}$ & 32.3 & 33.2 & 35.9 \\
\hline $\mathrm{NE}_{\mathrm{L}}, \mathrm{Mcal} / \mathrm{kg}$ & 1.56 & 1.63 & 1.65 \\
\hline Calcium & 0.71 & 0.68 & 0.72 \\
\hline Phosphorus & 0.46 & 0.44 & 0.47 \\
\hline Magnesium & 0.32 & 0.32 & 0.33 \\
\hline Potassium & 1.32 & 1.34 & 1.31 \\
\hline Sodium & 0.15 & 0.14 & 0.16 \\
\hline Chloride & 0.20 & 0.18 & 0.21 \\
\hline Sulfur & 0.23 & 0.22 & 0.23 \\
\hline Cobalt, $\mathrm{mg} / \mathrm{kg}$ & 0.57 & 0.53 & 0.60 \\
\hline Copper, $\mathrm{mg} / \mathrm{kg}$ & 15.0 & 14.4 & 15.5 \\
\hline Iodine, $\mathrm{mg} / \mathrm{kg}$ & 1.1 & 1.0 & 1.1 \\
\hline Manganese, $\mathrm{mg} / \mathrm{kg}$ & 159.1 & 168.7 & 152.6 \\
\hline Selenium, mg/kg & 0.43 & 0.44 & 0.46 \\
\hline Zinc, $\mathrm{mg} / \mathrm{kg}$ & 73.4 & 70.3 & 75.2 \\
\hline
\end{tabular}

${ }^{1} \mathrm{OSH}=$ outdoor-stored hay; $\mathrm{BSH}=$ barn-stored hay; $\mathrm{BAL}=$ baleage. ${ }^{2}$ Based on average forage and concentrate intake during the 42 -d feeding trial.

${ }^{3}$ Mineral and vitamin mix containing $22 \%$ calcium, $6 \%$ phosphorus, $4 \%$ magnesium, $1 \%$ potassium, $12 \%$ sodium chloride, $1.25 \%$ sulfur, 26 $\mathrm{mg}$ of cobalt $/ \mathrm{kg}, 560 \mathrm{mg}$ of copper $/ \mathrm{kg}, 50 \mathrm{mg}$ of iodine $/ \mathrm{kg}, 1,230 \mathrm{mg}$ of manganese $/ \mathrm{kg}, 2,715 \mathrm{mg}$ of zinc $/ \mathrm{kg}, 20 \mathrm{mg}$ of selenium $/ \mathrm{kg}, 330 \mathrm{kIU}$ of vitamin $\mathrm{A} / \mathrm{kg}, 66 \mathrm{kIU}$ of vitamin $\mathrm{D} / \mathrm{kg}$, and 1,100 IU of vitamin $\mathrm{E} / \mathrm{kg}$. ${ }^{4}$ Mean of 6 concentrate and forage samples taken weekly.

through August have been associated with the period of maximum plant florescence and yield (Cuomo et al., 1996; Interrante et al., 2009). Although the later cutting in our study was lower in protein and energy, diets in the feeding study were formulated to provide excess $\mathrm{CP}$ for mid lactation cows (Table 2), and the lower energy third cutting was fed during the second half of the study when milk yield and energy demand were declining.

Effects of conservation method on storage losses and nutritive value of bahiagrass are presented in Table 3 . Interactions of cutting date with conservation method were minimal; therefore, data are pooled over cutting dates. Initial hay moisture concentrations were less than $17 \%$, but the OSH increased moisture content, whereas the BSH decreased moisture content by 4.5 percentage units during the 6-mo storage period. High humidity and rainfall in Louisiana have been shown to increase moisture of outdoor-stored hay crops, leading to high storage and quality losses (Nelson et al., 1983). The BAL DM concentration was approximately 50\% 
Table 3. Effect of conservation method on nutritive value and storage losses of bahiagrass

\begin{tabular}{|c|c|c|c|c|c|}
\hline \multirow[b]{2}{*}{ Item } & \multicolumn{3}{|c|}{ Conservation method $^{1}$} & \multirow[b]{2}{*}{$P$-value ${ }^{2}$} & \multirow[b]{2}{*}{$\mathrm{SE}$} \\
\hline & $\mathrm{OSH}$ & $\mathrm{BSH}$ & $\mathrm{BAL}^{3}$ & & \\
\hline \multicolumn{6}{|l|}{ Nutritive value $^{4}$} \\
\hline Initial DM, \% & $83.6^{\mathrm{a}}$ & $84.2^{\mathrm{a}}$ & $49.7^{\mathrm{b}}$ & $<0.0001$ & 1.1 \\
\hline Final DM, \% & $79.7^{\mathrm{a}}$ & $88.7^{\mathrm{a}}$ & $50.2^{\mathrm{b}}$ & $<0.0001$ & 1.3 \\
\hline Initial protein, $\%$ & 12.2 & 12.0 & 12.4 & 0.3614 & 0.3 \\
\hline Final protein, $\%$ & 13.2 & 12.8 & 12.9 & 0.1612 & 0.3 \\
\hline Initial ADF, $\%$ & 37.2 & 37.2 & 37.5 & 0.5283 & 0.4 \\
\hline Final ADF, $\%$ & $44.4^{\mathrm{a}}$ & $38.8^{\mathrm{b}}$ & $39.5^{\mathrm{b}}$ & $<0.0001$ & 0.4 \\
\hline Initial NDF, $\%$ & 68.9 & 68.6 & 69.0 & 0.6895 & 0.7 \\
\hline Final NDF, $\%$ & $74.9^{\mathrm{a}}$ & $69.5^{\mathrm{b}}$ & $70.1^{\mathrm{b}}$ & $<0.0001$ & 0.7 \\
\hline Initial $\mathrm{NE}_{\mathrm{L}}, \mathrm{Mcal} / \mathrm{kg}$ & 1.36 & 1.36 & 1.36 & 0.5283 & 0.03 \\
\hline Final $\mathrm{NE}_{\mathrm{L}}, \mathrm{Mcal} / \mathrm{kg}$ & $1.17^{\mathrm{a}}$ & $1.32^{\mathrm{b}}$ & $1.32^{\mathrm{b}}$ & $<0.0001$ & 0.03 \\
\hline \multicolumn{6}{|l|}{ Storage losses } \\
\hline Initial fresh bale weight, $\mathrm{kg}$ & $575.9^{\mathrm{a}}$ & $599.1^{\mathrm{a}}$ & $680.5^{\mathrm{b}}$ & $<0.0001$ & 16.4 \\
\hline Final fresh bale weight, $\mathrm{kg}$ & $526.7^{\mathrm{a}}$ & $552.7^{\mathrm{b}}$ & $671.4^{\mathrm{c}}$ & $<0.0001$ & 15.5 \\
\hline DM loss, $\%$ & $12.8^{\mathrm{a}}$ & $2.9^{\mathrm{b}}$ & $0.3^{\mathrm{b}}$ & $<0.0001$ & 1.5 \\
\hline $\mathrm{NE}_{\mathrm{L}}$ loss, $\%$ & $10.4^{\mathrm{a}}$ & $4.6^{\mathrm{b}}$ & $1.6^{\mathrm{b}}$ & $<0.0001$ & 0.6 \\
\hline \multicolumn{6}{|c|}{${ }^{\mathrm{a}-\mathrm{C}}$ Means within a row with different superscripts differ $(P<0.05)$. } \\
\hline \multirow{3}{*}{\multicolumn{6}{|c|}{$\begin{array}{l}{ }^{1} \mathrm{OSH}=\text { outdoor-stored hay; } \mathrm{BSH}=\text { barn-stored hay; } \mathrm{BAL}=\text { baleage. } \\
{ }^{2} \mathrm{Conservation} \text { method by harvest date interactions were nonsignificant }(P>0.05) \text { except for } \mathrm{ADF}(P \\
0.0039) \text {. }\end{array}$}} \\
\hline & & & & & \\
\hline & & & & & \\
\hline \multicolumn{6}{|c|}{$\begin{array}{l}{ }^{4} \text { Initial forage samples }(\mathrm{n}=18 \text { bales per treatment) were collected at baling; final samples }(\mathrm{n}=18 \text { bales } \mathrm{p} \\
\text { treatment) were collected } 155 \mathrm{~d} \text { postharvest. }\end{array}$} \\
\hline
\end{tabular}

and changed little during storage. Previous research suggests an optimum DM range of between 35 and $70 \%$ for successful grass-crop baleage production (Bates, et al., 1989; Huhnke et al., 1997; McCormick et al., 2002). Other initial nutritive value measurements such as $\mathrm{CP}, \mathrm{ADF}$, and NDF were similar across conservation methods, indicating that treatment forages were very homogeneous at study initiation. Poststorage $\mathrm{CP}$ means did not differ with conservation method, but $\mathrm{ADF}$ and NDF of OSH were several percentage units higher than that of either BSH or BAL. Elevated fiber concentrations resulted in a $12.8 \%$ depression in $\mathrm{NE}_{\mathrm{L}}$ for OSH compared with bahiagrass conserved as BSH or BAL. Nelson et al. (1983) noted similar increases in lignin and ADF and depressions in digestibility of annual ryegrass hay stored outside on the ground for 7 mo. Although they did not detect differences in CP between indoor- and outdoor-stored hays, they did record a $30.7 \%$ decline in available protein, reportedly affiliated with enzymatic browning that increased ADIN concentrations in outdoor-stored hay. Most declines in outdoor hay quality are associated with weathering, which takes place on the outer $10 \mathrm{~cm}$ of outdoor-stored round hay bales (Collins et al., 1995).

Although baleage bales were smaller than hay bales, fresh baleage bale weights were substantially $(P<0.01)$ heavier than hay bales (Table 3). However, on a dry weight basis, the postensiled baleage bales contained only $73.8 \%$ of the DM found in OSH and BSH. En- ergy and DM losses were the highest $(P<0.01)$ for OSH, but did not differ between BSH and BAL $(P>$ $0.05)$. Dry matter losses of $12.8 \%$ for OSH reported in the present study were comparable to $15 \%$ alfalfa DM loss and $18 \%$ tall fescue DM loss recorded for outdoorstored hay (Belyea et al., 1985; Collins et al., 1995). In contrast, Nelson et al. (1983) reported a 37.7\% DM loss for annual ryegrass hay stored outside on the ground for a 7-mo period. Differences between studies may be related to such factors as forage species, initial forage quality, bale density, and environment. Energy and DM losses for bahiagrass conserved as BSH and BAL were less than one-fourth of that observed for OSH, generally averaging less than $5 \%$ of initial values. These data substantiate findings from earlier studies that noted low storage losses for barn-stored hay (Nelson et al., 1983; Belyea et al., 1985; Collins et al., 1995) and properly managed baleage (Collins et al., 1995; Huhnke et al., 1997; McCormick et al., 1998). Although most studies indicate that baleage storage losses are comparable to those of barn-stored hay, high storage losses (12\% of DM) were recorded for direct-cut, high-moisture bermudagrass stored as baleage (Bates et al., 1989).

\section{Lactation Performance}

Performance data of Holstein cows as influenced by bahiagrass conservation method are presented in Table 4. Concentrate DMI was similar across conservation 
Table 4. Performance data of Holstein cows as influenced by bahiagrass conservation method

\begin{tabular}{lccccc}
\hline & \multicolumn{3}{c}{ Conservation method } & & \\
\cline { 2 - 3 } Item & OSH & BSH & BAL & SE & $P$-value \\
\hline Cows, n & 10 & 10 & 10 & & \\
Concentrate DMI, kg/d & 11.1 & 11.2 & 11.2 & 0.02 & 0.99 \\
Forage DMI, kg/d & $9.3^{\text {ab }}$ & $10.9^{\mathrm{a}}$ & $8.4^{\mathrm{b}}$ & 0.8 & 0.09 \\
DMI, kg/d & $20.5^{\mathrm{ab}}$ & $22.1^{\mathrm{a}}$ & $19.6^{\mathrm{b}}$ & 0.8 & 0.09 \\
DMI, \% BW & 3.10 & 3.30 & 2.96 & 0.16 & 0.39 \\
BW, kg & 660.9 & 669.5 & 662.1 & 10.3 & 0.82 \\
BW change, kg/42 d & 6.3 & -19.1 & -4.8 & 8.3 & 0.45 \\
BCS (1-5) & 2.43 & 2.52 & 2.41 & 0.08 & 0.58 \\
BCS change, unit/42 d & -0.16 & -0.16 & -0.06 & 0.06 & 0.31 \\
Milk yield and efficiency & & & & \\
Milk, kg/d & $28.2^{\mathrm{b}}$ & $30.2^{\mathrm{a}}$ & $29.0^{\mathrm{ab}}$ & 0.6 & 0.09 \\
3.5\% FCM, kg/d & 27.7 & 29.6 & 28.7 & 1.0 & 0.35 \\
M.5\% FCM:DMI & 1.35 & 1.36 & 1.48 & 0.07 & 0.33 \\
Milk composition & & & & & \\
Fat, \% & 3.46 & 3.42 & 3.39 & 0.13 & 0.93 \\
Fat, kg/d & 0.96 & 1.00 & 0.99 & 0.06 & 0.85 \\
Protein, \% & 3.02 & 3.00 & 3.03 & 0.07 & 0.97 \\
Protein, kg/d & 0.85 & 0.85 & 0.86 & 0.03 & 0.91 \\
Lactose, \% & 4.99 & 4.87 & 4.94 & 0.08 & 0.60 \\
Lactose, kg/d & 1.41 & 1.47 & 1.43 & 0.10 & 0.91 \\
SCC, $\times 1,000$ cells/mL & 135 & 322 & 237 & 66 & 0.15 \\
\hline
\end{tabular}

${ }^{\mathrm{a}, \mathrm{b}}$ Means within a row with different superscripts differ $(P<0.10)$.

${ }^{1} \mathrm{OSH}=$ outdoor-stored hay; $\mathrm{BSH}=$ barn-stored hay; $\mathrm{BAL}=$ baleage.

methods and averaged $11.2 \mathrm{~kg} / \mathrm{cow}$ per day. Forage DMI did not differ $(P>0.05)$ among treatments although intake of BSH was numerically higher than that of either OSH or BAL. The tendency for BAL to be consumed at a lower rate than BSH was unexpected because BAL DM concentration $(\mathrm{DM}=50.2 \%)$ was in the optimum range required for high DMI (Bates et al., 1989; Dawson et al., 1999). In addition, NDF concentrations were similar between treatments, negating the possible influence of fiber on DMI. These findings may be related to ambient temperature because this study was conducted during the winter and earlier research at this unit evaluating ryegrass baleage in milking cows indicated a preference for baleage in warmer temperatures and for hay in cooler temperatures (McCormick et al., 1998). Aerobic stability is often a concern when evaluating consumption of ensiled crops, but the present study was conducted in the cooler months (February through April), which, in combination with the low water-soluble carbohydrate of bahiagrass (M. E. McCormick, unpublished data), would tend to retard secondary yeast and mold proliferation (Weinberg et al., 1993). Furthermore, intake by growing heifers fed native tropical grass stored as baleage was not affected by aerobic exposure of the silage for up to $72 \mathrm{~h}$ before feeding (González and Rodriguez, 2003). Because the present study was conducted in moderately low temperatures, with a crop containing minimal quantities of residual water-soluble carbohydrate, and the silage was fed within $48 \mathrm{~h}$ of exposure to air, extensive aerobic deterioration of BAL would not seem likely. Nonetheless, more research needs to be conducted on aerobic stability and its relationship with intake of baleage crops, particularly with high-sugar crops such as annual ryegrass and sorghum (Sorghum bicolor L.) offered at high ambient temperatures.

Similarly, a trend was observed for BSH to be consumed more readily than OSH in the present study. This was likely a consequence of the higher NDF concentrations present in OSH (Table 3). Comparisons between indoor- and outdoor-stored hay with lactating dairy cattle are limited. Belyea et al. (1985) reported an $11.4 \%$ DMI increase for barn-stored hay consumption compared with outdoor-stored hay for yearling Holstein calves.

Actual milk yield and 3.5\% FCM yield did not differ with forage conservation method $(P<0.05)$. A trend $(P$ $<0.09$ ) was observed for milk yield to follow a pattern similar to that observed for DMI, with BSH producing about $7.1 \%$ more milk than OSH. The tendency for DMI to be lower for BAL than for BSH with similar $3.5 \%$ FCM production resulted in a slight improvement $(P<0.07)$ in feed efficiency ( $1: 48$ vs. 1.36 FCM:DMI) for BAL compared with the other 2 forage conservation systems. No direct comparisons on milk yield between same-day-cut hay and baleage were available in the 
literature. However, the shorter wilting period required for baleage than for hay allowed cool-season forage crops such as annual ryegrass and orchard grass to be harvested as much as 2 wk earlier in the spring, which led to higher milk yield among baleage-fed cows (McCormick et al., 1998; Borreani et al., 2007). In another earlier trial, Canadian researchers found that DMI and milk yield were lower for same-day-harvested timothy or quackgrass stored as baleage compared with that stored as precision-cut haylage, this being related to higher $\mathrm{pH}$ and longer particle length of the baleage crop (Petit et al., 1993). No hay treatment was used in the Canadian work.

Milk fat, protein, and lactose concentrations were similar across treatments. This lack of effect on milk composition was somewhat unexpected because dietary forage to grain ratios varied from a high of $49.3 \%$ for BSH to a low of $42.9 \%$ for BAL. This lack of response, especially with milk fat composition, may suggest differences in fiber digestibility or cud chewing behavior between forages conserved as hay or BAL. Cow BW, $\mathrm{BCS}$, and study-long differences in BW and BCS were similar $(P>0.05)$ across forage conservation systems.

In summary, same-day-harvested bahiagrass conserved as OSH showed higher DM losses, resulting in lower nutritive value and a tendency for lower DMI and milk yield than BSH. Storage losses, nutritive value, and lactation performance were similar for $\mathrm{BSH}$ and BAL. These data indicate that the baleage conservation system may substitute for indoor-stored hay systems without expectation of increased storage losses or declines in animal performance. Moreover, producers who have traditionally stored bahiagrass round bale hay outdoors may realize substantial reductions in DM losses and improved animal performance by storing hay indoors or purchasing a bale wrapper and adopting the baleage conservation system.

\section{ACKNOWLEDGMENTS}

The authors thank Doug McKean, Bill Barber, and Dennis Morgan of the Southeast Research Station (Franklinton, LA) for assisting with animal management and laboratory analyses during this study.

\section{REFERENCES}

AOAC. 1990. Official Methods of Analysis. 15th ed. AOAC, Arlington, VA.

Bates, D. B., W. E. Kunkle, C. G. Chambliss, and R. P. Cromwell 1989. Effect of dry matter and additives on bermudagrass and rhizoma peanut round bale silage. J. Prod. Agric. 2:91-96.

Belyea, R. L., F. A. Martz, and S. Bell. 1985. Storage and feeding losses of large round bales. J. Dairy Sci. 68:3371-3375.
Berthe, A., W. E. Kunkle, C. G. Chambliss, and D. B. Bates. 1991. Effects of harvesting system and wilting on bermudagrass intake and live weight change of growing heifers. J. Anim. Sci. 69(Suppl. 1):283. (Abstr.)

Borreani, G., D. Giaccone, A. Mimos, and E. Tabacco. 2007. Comparison of hay and haylage from permanent alpine meadows in winter dairy cow diets. J. Dairy Sci. 90:5643-5650.

Collins, M., L. D. Swetman, G. M. Turner, J. N. Hancock, and S. A. Shear. 1995. Storage method effects on dry matter and quality losses of tall fescue round bales. J. Prod. Agric. 8:507-513.

Cuomo, G. J., D. C. Blouin, D. L. Corkern, J. E. McCoy, and R. Walz. 1996. Plant morphology and plant nutritive value of three bahia grasses as affected by harvest frequency. Agron. J. 88:85-89.

Dawson, L. E. R., C. P. Ferris, R. W. Steen, F. J. Gordon, and D. J. Kilpatrick. 1999. The effects of wilting grass before ensiling on silage intake. Grass Forage Sci. 54:237-247.

Edmonson, A. J., I. J. Lean, L. D. Weaver, T. Farver, and G. Webster. 1989. A body condition scoring chart of Holstein dairy cows. J. Dairy Sci. 72:68-78.

González, G., and A. A. Rodriguez. 2003. Effect of storage method on fermentation characteristics, aerobic stability, and forage intake of tropical grasses ensiled in round bales. J. Dairy Sci. 86:926-933.

Han, K. J., M. Collins, E. S. Vanzant, and C. T. Dougherty. 2006. Characteristics of baled silage made from first and second harvests of wilted and severely wilted forages. Grass Forage Sci. 61:2231.

Han, K. J., and M. E. McCormick. 2010. Analyses of Mississippi and Louisiana producers samples reveal mineral status of forages. Forage and Grazinglands. Accessed June 16, 2010. www.plantmanagementnetwork.org/pub/fg/research/2010. 10.1094/FG-20100616$01-\mathrm{R}$

Huhnke, R. L., R. E. Muck, and M. E. Payton. 1997. Round bale silage storage losses of ryegrass and legume-grass forages. Appl. Eng. Agric. 13:451-457.

Interrante, S. M., L. E. Sollenger, A. R. Blount, U. R. White, and S. W. Coleman. 2009. Defoliation management of bahiagrass germplasm affects dry matter yield and herbage nutritive value. Agron. J. 101:989-995.

Kunkle, W. E., D. B. Bates, C. G. Chambliss, and R. P. Cromwell. 1988. Alternative forage storage: Bale silage. Proc. Dairy Herd Mgmt. Conf., Univ. of Georgia, Athens.

Leonardi, C., V. R. Moreira, R. D. Bardwell, M. E. McCormick, M. Autin, B. Perez, and M. C. C. Martinez. 2008. An assessment of current feeding practices in Louisiana dairy farms - Preliminary results. Pages 15-18 in Louisiana State University AgCenter Southeast Res. Stn. Field Day Summary. Louisiana State University, Baton Rouge.

McCormick, M. E., J. F. Beatty, and J. M. Gillespie. 2002. Ryegrass bale silage research and management practices. Louisiana State University Agricultural Center Res. Sum. 144:1-16. Louisiana State University, Baton Rouge.

McCormick, M. E., G. J. Cuomo, and D. C. Blouin. 1998. Annual ryegrass stored as balage, haylage, or hay for lactating dairy cows. J. Prod. Agric. 11:293-300.

Montgomery, C. R., M. Allen, J. G. Kowalczuk, P. E. Schilling, and L. F. Mason. 1979. Nutritional and agronomic comparisons of four warm-season perennial grasses. Louisiana Agric. Exp. Stn. Bull. $715: 1-28$.

Nelson, B. D., and C. R. Montgomery. 1975. Comparison of chemical analysis and in vitro fermentation techniques for forage quality evaluation. Pages 130-137 in Southeast Res. Stn. Ann. Prog. Rep. Louisiana Agric. Exp. Stn., Franklinton.

Nelson, B. D., L. R. Verma, and C. R. Montgomery. 1983. Effects of storage method on losses and quality changes in round bales of ryegrass and alfalfa hay. Louisiana Agric. Exp. Stn. Bull. 750:119.

NRC. 2001. Nutrient Requirements of Dairy Cattle. 7th rev. ed. Natl. Acad. Sci., Washington, DC.

Petit, H. V., G. F. Tremblay, P. Savoie, D. Tremblay, and J. M. Wauthy. 1993. Milk yield, intake, and blood traits of lactating cows 
fed grass silage conserved under different harvesting methods. J. Dairy Sci. 76:1365-1374.

SAS Institute. 2001. User's Guide: Statistics, Version 8.1, 1st ed. SAS Inst. Inc., Cary, NC.

Straub, R. J., R. G. Koegel, and K. J. Shinners. 1990. Alternative methods for big bale silage. Paper No. 90-1519 in Proc. Am. Soc. Agric. Eng. Mtg., Chicago, IL. Am. Soc. Agric. Eng., St. Joseph, MI.
Van Soest, P. J., J. B. Robertson, and B. A. Lewis. 1991. Methods for dietary fiber, neutral detergent fiber, and non-starch polysaccharides in relation to animal nutrition. J. Dairy Sci. 74:3583-3597.

Weinberg, Z. G., G. Ashbell, Y. Hen, and A. Azriell. 1993. The effect of adding lactic acid bacteria at ensiling on the aerobic stability of silages. J. Appl. Bacteriol. 75:512-518. 